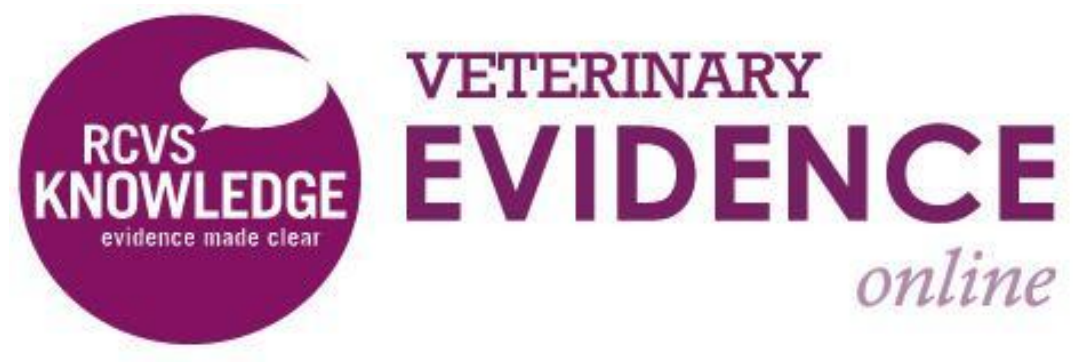

\title{
Are Dogs That Eat Quickly More Likely to Develop a Gastric Dilatation (+/- Volvulus) Than Dogs That Eat Slowly?
}

\author{
A Knowledge Summary by \\ Louise Anne Buckley PhD RVN* \\ ${ }^{1}$ Harper Adams University, Edgmond, Newport TF10 8NB
${ }^{*}$ Corresponding Author (Ibuckley@harper-adams.ac.uk)
}

ISSN: 2396-9776

Published: 13 Dec 2016

in: Vol 1, Issue 4

DOI: http://dx.doi.org/10.18849/ve.v1i4.53

Reviewed by: Gillian Monsell (MA VetMB PhD MRCVS)

Bruce Smith (BVSc MS FANZCVS DACVS)

Next Review Date: 13 Dec 2018 
KNOWLEDGE SUMMARY

\section{Clinical bottom line}

The available evidence is mixed and of variable quality. Most evidence indicates that rate of eating has no effect on risk of gastric dilatation - volvulus (GDV). Where significant effects occur, fast eating was implicated as a risk factor. No studies found that slow eating was significantly associated with an increased risk of GDV. Slowing the rate at which a dog consumes a meal will not increase risk of GDV but it may possibly reduce the risk. Based on the limitations and unreliability of the current relevant literature there is not enough evidence to make a conclusion either way.

\section{Question}

Are dogs that eat quickly more likely to develop a gastric dilatation (+/-volvulus) than dogs that eat slowly?

\section{Clinical scenario}

A client approaches the clinic for advice on reducing the risk of their dog developing a gastric dilatation volvulus (GDV) as they have heard that their particular breed of dog is particularly at risk from this condition. They have read on the internet that they should buy a go slow / anti-gulp feeding bowl to slow down the speed at which their dog eats because eating quickly is a risk factor for developing this condition. They want to know if there is any evidence that slowing down a dog's rate of eating does reduce the risk of the dog developing a GDV.

\section{The evidence}

The literature searches uncovered six papers (Glickman et al., 1997; Elwood, 1998; Theyse et al., 1998; Glickman et al. 2000; Raghavan et al., 2004; Pipan et al. 2012) that directly addressed the PICO question. Of these, four of the studies (Elwood, 1998; Theyse et al., 1998; Raghavan et al., 2004; Pipan et al., 2012) found no significant effect of speed of eating on risk of having a GDV episode. One paper (Glickman et al., 1997) found that dogs that ate quickly were significantly more likely to present at a clinic with a GDV episode. The final paper (Glickman et al., 2000) found that large breed dogs (but not giant breeds) were significantly more likely to develop a GDV if they ate fast, but the $95 \%$ confidence intervals associated with the relative risk value that the authors report suggests that the true risk may not differ from that of slow eaters.

\section{Summary of the evidence}

\section{Pipan (2012)}

\begin{tabular}{|c|l|}
\hline Population: & $\begin{array}{l}\text { Privately owned dogs (any breed or mix, both sexes, neutered and } \\
\text { entire) across a wide geographic area. } \\
\text { The survey was potentially available to English speaking dog owners } \\
\text { with access to the internet in any country worldwide. }\end{array}$ \\
\hline Sample size: & $\begin{array}{r}2551 \text { surveys included in the analysis: } \\
\text { - Control group (dogs without a GDV): } 1437 \text { respondents } \\
\text { - Gastric dilatation - volvulus group (GDV): } 1114 \text { respondents }\end{array}$ \\
\hline
\end{tabular}




\begin{tabular}{|c|c|}
\hline Intervention details: & $\begin{array}{l}\text { Online survey based study, with ad hoc convenience sampling of dog } \\
\text { owners. } \\
\text { The questionnaire was divided into three sections: } \\
\text { 1. Demographic information (year of birth, breed, sex, neuter } \\
\text { status, and purpose of the dog; country and postcode of } \\
\text { respondent). Whether the dog had ever had a GDV that } \\
\text { required surgical intervention. This latter question was used } \\
\text { to divide dogs into the control group and the GDV group. } \\
\text { However, the authors then also included within the GDV } \\
\text { group dogs that did not have surgery, or died / were } \\
\text { euthanised without surgery but were considered to have a } \\
\text { GDV (whether confirmed or presumed). } \\
\text { 2. GDV group: a series of } 44 \text { questions divided into } 4 \\
\text { categories: } \\
\text { i. Dog specific factors } \\
\text { ii. } \quad \text { Management factors } \\
\text { iii. } \quad \text { Environmental factors } \\
\text { iv. Personality factors } \\
\text { 3. Control group: The same questions were asked of the } \\
\text { control group dog owners as were asked of the GDV group, } \\
\text { with the exception that they were not asked any questions } \\
\text { about the GDV episode (as the dogs had not experienced a } \\
\text { GDV). They were asked one additional question (had the dog } \\
\text { had a prophylactic gastroplexy?). These changes reduced the } \\
\text { total number of questions asked to } 32 \text {. }\end{array}$ \\
\hline Study design: & Cross-sectional study \\
\hline Outcome studied: & $\begin{array}{l}\text { The outcome measure was a GDV episode in the dog's history. The } \\
\text { study looked for factors that were associated with an increased } \\
\text { incidence of GDV in the population studied. } \\
\text { Of relevance to this PICO, the authors' asked owners to rate, on a } \\
\text { scale of } 1 \text { to 5, the speed with which their dog consumed its food } \\
\text { ration. }\end{array}$ \\
\hline $\begin{array}{l}\text { Main findings: } \\
\text { (relevant to PICO question): }\end{array}$ & $\begin{array}{l}\text { The findings in relation to speed of eating are not reported within } \\
\text { the results section. The authors note in the discussion that speed of } \\
\text { eating was not significantly associated with risk of GDV. }\end{array}$ \\
\hline Limitations: & $\begin{array}{l}\text { The primary limitation is the failure to report their findings (along } \\
\text { with numerical data) within the results section as this precludes the } \\
\text { reader making an independent assessment of their conclusion. } \\
\text { The measurement of speed of eating on a scale of } 1-5 \text { will be } \\
\text { sensitive to owner subjectivity in assessment. The authors do not } \\
\text { provide any information on how owners were guided (if at all) to } \\
\text { select the number that most represented their dog. Further, the }\end{array}$ \\
\hline
\end{tabular}




\begin{tabular}{|l|l|}
\hline $\begin{array}{l}\text { incidents of GDV were retrospective so owners may have already } \\
\text { taken measures to reduce their dog's speed of eating post-surgery, } \\
\text { on the basis of veterinary recommendation or lay research. The } \\
\text { authors do not outline whether owners were asked to complete the } \\
\text { form on the basis of the dog's feeding behavior at the time of (or } \\
\text { preceding) the GDV, or present time, or not directed as to a time } \\
\text { frame to use. }\end{array}$ \\
$\begin{array}{l}\text { There was no attempt to match control dogs and GDV dogs across } \\
\text { other dimensions that may have been relevant (e.g. breed, size, and } \\
\text { / or age). } \\
\text { The population of dogs studied is not constrained to types of dogs at } \\
\text { high risk of GDV (large and giant breed dogs). Therefore, if any risk } \\
\text { factors identified co-vary with the size of the dog, this would } \\
\text { represent a confounding variable in interpreting the data that limits } \\
\text { any conclusions that may be drawn. }\end{array}$ \\
\hline
\end{tabular}

\begin{tabular}{|c|c|}
\hline \multicolumn{2}{|l|}{ Glickman (2000) } \\
\hline Population: & $\begin{array}{l}\text { Dogs (male, female, neutered and entire) from eleven different large } \\
\text { and giant dog breeds (Akita, Bloodhound, Collie, Great Dane, Irish } \\
\text { Setter, Irish Wolfhound, Newfoundland, Rottweiler, Saint Bernard, } \\
\text { Standard Poodle, and Weimaraner), that were located within the } \\
\text { USA. Dogs were required to be at least } 6 \text { months old and not to have } \\
\text { a medical history that included an episode of GDV before the study } \\
\text { commenced. }\end{array}$ \\
\hline Sample size: & $\begin{array}{l}1637 \text { (large breeds: } n=894 \text {; giant breeds: } n=743 \text { ): } \\
\text { - Dogs that developed a GDV during the course of the study: } \\
98 \\
\text { - Dogs that did not develop a GDV during the course of the } \\
\text { study: } 1539 \\
\text { Nb. This study was derived from a larger prospective cohort study } \\
\text { carried out by the authors. } 1991 \text { dogs initially enrolled on this study; } \\
\text { however, for inclusion in the current study (which used data from } \\
\text { the larger study), certain criteria needed to be met and this reduced } \\
\text { the sample size. Further details are outlined in the intervention } \\
\text { section. }\end{array}$ \\
\hline Intervention details: & $\begin{array}{l}\text { The study began in June } 1994 \text { and ended in February } 1999 . \\
\text { Therefore, the maximum possible period that a dog could be studied } \\
\text { for was } 58 \text { months. } \\
\text { Dogs were recruited through breed clubs and dog shows. At the start } \\
\text { of the study, owners were asked about the presence of GDV in the } \\
\text { medical history of the dog or any of its first-degree relatives. The dog } \\
\text { was physically assessed for body condition and temperament, and } \\
\text { conformational measurements taken. }\end{array}$ \\
\hline
\end{tabular}




\begin{tabular}{|c|c|}
\hline & 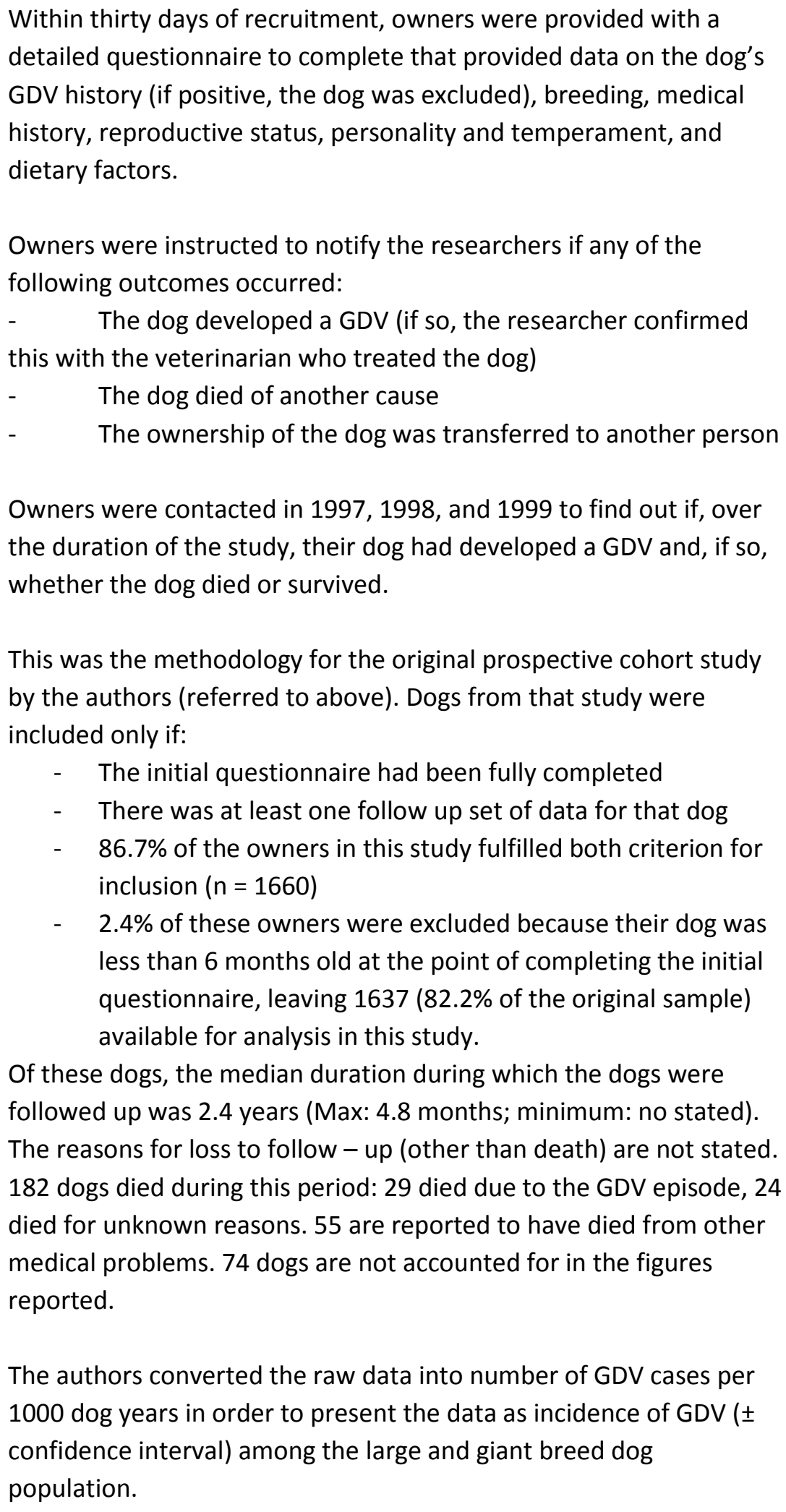 \\
\hline Study design: & Prospective cohort study \\
\hline Outcome studied: & $\begin{array}{l}\text { The outcome measure was whether the dog developed an episode } \\
\text { of GDV during the course of the study and whether it survived this } \\
\text { episode. The study then looked for non- dietary related factors that } \\
\text { were associated with an increased risk of developing GDV in the }\end{array}$ \\
\hline
\end{tabular}




\begin{tabular}{|c|c|}
\hline & $\begin{array}{l}\text { population studied. } \\
\text { Of relevance to this PICO, the authors' asked owners to rate, on a } \\
\text { scale of } 1 \text { (slow) to } 10 \text { (fast), the speed with which their dog } \\
\text { consumed its food ration. The authors did not direct the owners } \\
\text { further as to what constituted e.g. a rating of ' } 3 \text { ', but, instead, the } \\
\text { owner was left to use their judgement and experience. } \\
\text { In analysing and presenting the data, the authors' merged speed } \\
\text { ratings to form three categories: } \\
\text { a. Slow: speed rating of } 1-3 \\
\text { b. Average: Speed rating of } 4-6 \\
\text { c. Fast: Speed rating of } 7-10 \\
\text { And then, further split the data into: } \\
\text { a. Large breed dogs } \\
\text { b. Giant breed dogs }\end{array}$ \\
\hline $\begin{array}{l}\text { Main findings: } \\
\text { (relevant to PICO question): }\end{array}$ & 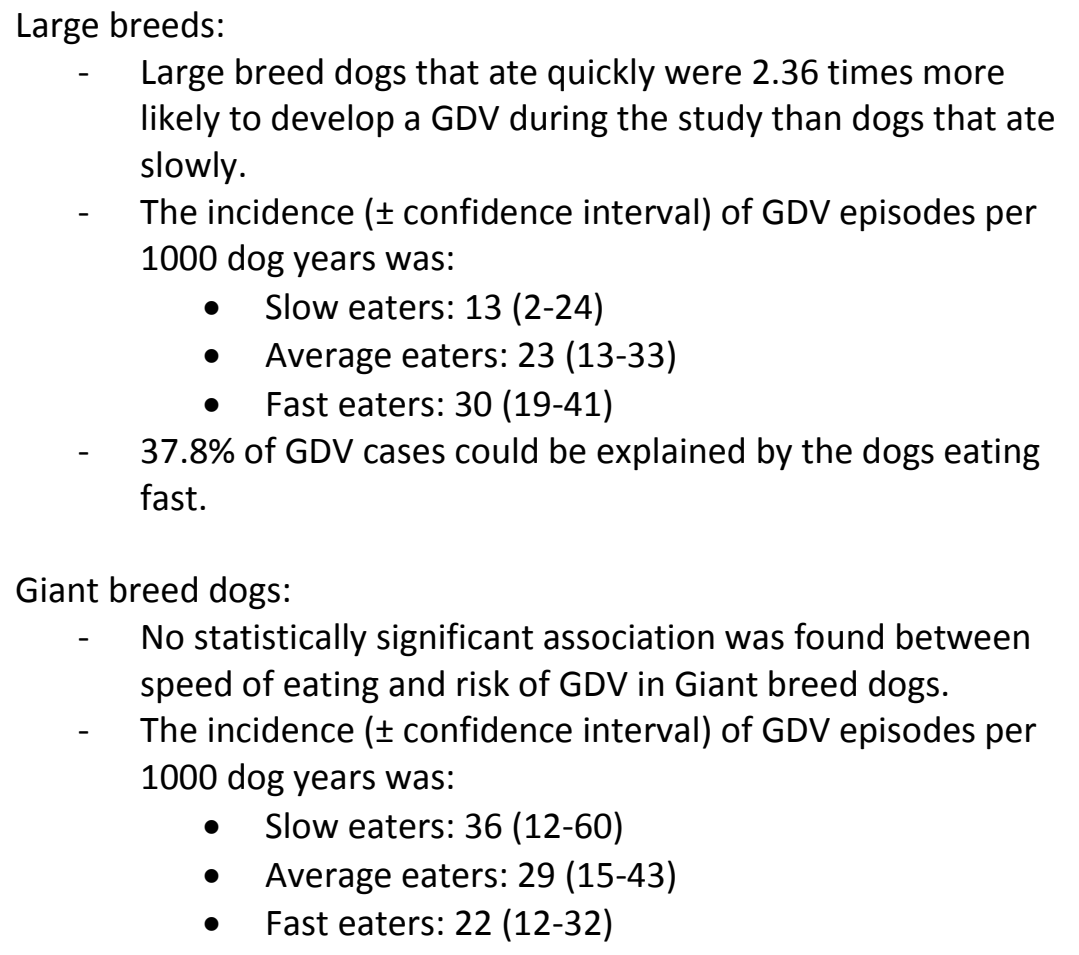 \\
\hline Limitations: & $\begin{array}{l}\text { The authors use the proportional hazards model to calculate the risk } \\
\text { of having a GDV, as a function of speed of eating score, and include } \\
\text { an interaction between breed size (large versus giant). However, the } \\
\text { population attributable relative risk of GDV that they report for fast } \\
\text { eating in large breed dogs ( } 2.36 \text { times more likely) is drawn from } \\
\text { their univariate analysis. The } 95 \% \text { confidence interval for this is } 0.91 \\
-6.12 \text {, which is both a wide range (giving less confidence in the } 2.36 \\
\text { value reported) and overlaps an odds ratio of } 1.0 \text { (awarded to the } \\
\text { slow eating group to which the other groups are compared), } \\
\text { indicating that, based on the univariate analysis, the true relative } \\
\text { risk may not differ between slow and fast eaters. }\end{array}$ \\
\hline
\end{tabular}




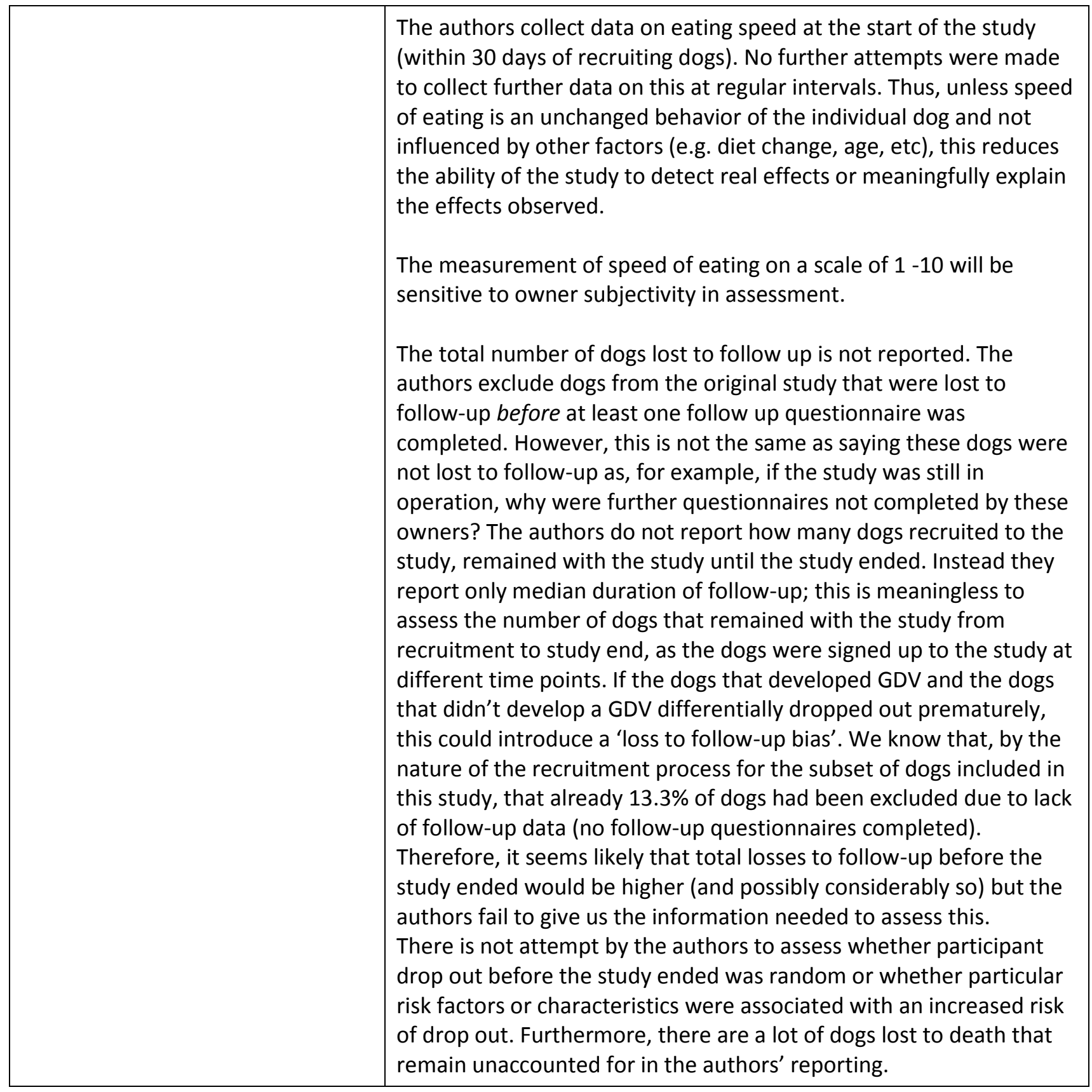

Theyse (1998)

\begin{tabular}{|c|c|}
\hline Population: & Great Danes. \\
\hline Sample size: & $\begin{array}{l}109 \text { dogs: } \\
-\quad 38 \text { dogs that had presented at the authors' vet clinic with a } \\
\text { GDV } \\
\text { - } \quad 71 \text { dogs owned by members of a Great Dane breed society }\end{array}$ \\
\hline Intervention details: & $\begin{array}{l}\text { Clinic records were retrospectively searched for cases of acute GDV } \\
\text { in Great Danes presented to the clinic over a } 14 \text { year period (January } \\
1981 \text { - December 1994). No information is provided on the fate } \\
\text { (survived or died) of the dogs that attended the clinic. } \\
\text { Control dogs were obtained by contacting a Great Dane breed }\end{array}$ \\
\hline
\end{tabular}




\begin{tabular}{|c|c|}
\hline & $\begin{array}{l}\text { society. } \\
\text { Owners of both groups of Great Danes were asked to complete a } \\
\text { questionnaire that asked owners about their feeding and exercise } \\
\text { regime. } \\
\text { Demographic information was also recorded (age, sex, neuter status, } \\
\text { and, for GDV dogs only, type of food eaten before the GDV episode) }\end{array}$ \\
\hline Study design: & $\begin{array}{l}\text { A cross sectional study (based on the RCVS Knowledge's Knowledge } \\
\text { Summary guide); the authors describe it as a case-control study }\end{array}$ \\
\hline Outcome studied: & $\begin{array}{l}\text { Of relevance to this PICO, the authors assessed speed of eating by } \\
\text { asking owners whether their dog took more than, or less than, five } \\
\text { minutes to consume its feed ration. }\end{array}$ \\
\hline $\begin{array}{l}\text { Main findings: } \\
\text { (relevant to PICO question): }\end{array}$ & $\begin{array}{l}\text { A significant association between food intake time and development } \\
\text { of a GDV was not observed. } \\
\text { No further information is provided. }\end{array}$ \\
\hline Limitations: & $\begin{array}{l}\text { The use of a binary less than, or more than, five minutes to consume } \\
\text { a feed ration is a crude assessment tool: } \\
\text { - } \text { Owners were not specifically asked to measure length of } \\
\text { time taken so it probably represents a variable and } \\
\text { subjective assessment } \\
\text { - The authors also ask owners whether they feed their dog } \\
\text { once, twice or more often per day. Dogs that consume } \\
\text { several meals will have smaller portions per feeding session } \\
\text { and so be more likely to consume a ration within five } \\
\text { minutes. Therefore, there may be a partial confound in the } \\
\text { findings between size of portion and time taken to consume } \\
\text { the ration. This weakens its use as a measure to assess } \\
\text { speed of eating. } \\
\text { There is no evidence that the authors tried to control for this } \\
\text { statistically (e.g. by only analysing the dogs that were fed } \\
\text { once daily). } \\
\text { The authors provide no numerical data to support their assertion } \\
\text { that there was no significant effect of food intake time. } \\
\text { The authors retrospectively searched clinic records for GDV cases in } \\
\text { Great Danes between } 1981 \text { and } 1994 \text { and owners of affected dogs } \\
\text { contacted to complete a questionnaire that retrospectively assessed } \\
\text { feeding and exercise regime. } \\
\text { - Thus, owners were often being asked to recall information } \\
\text { about their dog's exercise and diet regime many years after } \\
\text { the GDV episode and / or likely death of their dog. Factual } \\
\text { recall is likely to be poor under these circumstances. } \\
\text { Whereas, control group owners were probably being asked } \\
\text { about an existing, current dog that they own (not enough } \\
\text { information is provided to say this for certain). } \\
\text { Alternatively, dietary and exercise regime modifications may }\end{array}$ \\
\hline
\end{tabular}




\begin{tabular}{|c|c|}
\hline & $\begin{array}{l}\text { have been implemented post-acute GDV episode (in the } \\
\text { dogs that survived) and these reported by the owner as their } \\
\text { regime. This would prevent accurate measurement of risk } \\
\text { factors associated with GDV development. There is not } \\
\text { enough detail provided by the authors to allow this } \\
\text { possibility to be evaluated. }\end{array}$ \\
\hline \multicolumn{2}{|l|}{ Glickman (1997) } \\
\hline Population: & Owned dogs within the USA. \\
\hline Sample size: & 202 dogs (101 matched case-control pairings). \\
\hline Intervention details: & $\begin{array}{l}\text { Several veterinary practices were contacted to complete a clinical } \\
\text { data sheet for dogs that were presented at the clinic, diagnosed with } \\
\text { GDV, and whose owners were willing to be contacted by } \\
\text { researchers. Vets were asked to also identify a similar dog (matched } \\
\text { for age and breed if pure breed, or age and weight if cross bred). } \\
\text { Researchers provided their own case control dog through the } \\
\text { university veterinary hospital if vets were unable to. } \\
\text { All owners (GDV, and case-matched control) were interviewed by } \\
\text { phone. Data on the following areas were collected: } \\
\text { - } \quad \text { The owner of the animal } \\
\text { - Environmental factors } \\
\text { - Clinical history } \\
\text { - Physical activities } \\
\text { - Dietary factors } \\
\text { - Personality and temperament } \\
\text { Two types of questions were asked: } \\
\text { 1. Those designed to evaluate the dog in the } 8 \text { hours preceding } \\
\text { the GDV episode (GDV dogs) or telephone interview (case - } \\
\text { control dogs) } \\
\text { 2. Those designed to evaluate the dog's behavior. Diet, etc } \\
\text { more generally over the preceding year. } \\
\text { Of particular importance to this PICO was rate of eating. This is } \\
\text { mentioned in the abstract and results section but the authors fail to } \\
\text { mention in the methods section either rate of eating per se or how } \\
\text { this was assessed by the owners or quantified by the researchers. In } \\
\text { the results section, the authors refer to slow, moderate, and fast } \\
\text { groupings in relation to rate of eating, but how dogs were allocated } \\
\text { to these groupings remains unclear. }\end{array}$ \\
\hline Study design: & $\begin{array}{l}\text { A cross sectional study (based on the RCVS Knowledge's Knowledge } \\
\text { Summary guide); the authors' describe it as a case-control study }\end{array}$ \\
\hline Outcome studied: & $\begin{array}{l}\text { Of relevance to this PICO, owners were asked about rate of eating. } \\
\text { However, the authors fail to provide any information about whether } \\
\text { this was objectively quantified or represented a subjective } \\
\text { impression of the dog's feeding behavior. }\end{array}$ \\
\hline
\end{tabular}




\begin{tabular}{|c|l|}
\hline $\begin{array}{r}\text { Main findings: } \\
\text { (relevant to PICO question): }\end{array}$ & $\begin{array}{l}\text { Dogs that have a moderately fast (P=0.05) or fast rate of eating are } \\
\text { significantly more likely (P = 0.005) to have presented at the clinic } \\
\text { with a GDV than dogs that ate slowly. } \\
\text { Compared with slow eaters, dogs that ate moderately fast were } 2.59 \\
(1.01-6.79,95 \% \text { confidence interval) times more likely to have } \\
\text { developed a GDV. Fast eaters were } 4.72 \text { (1.57 - 14.24, 95\% C.I.) } \\
\text { times more likely to have developed a GDV, than slow eaters. }\end{array}$ \\
\hline Limitations: & $\begin{array}{l}\text { Failure to report any information about how speed of eating was } \\
\text { assessed represents a failing in this study as it is difficult to critique } \\
\text { the approach used or draw any conclusions as to the validity or } \\
\text { otherwise of the method. }\end{array}$ \\
& $\begin{array}{l}\text { It is not clear how many dogs (total; GDV; case-controlled pairs) } \\
\text { were represented within each of the groups (slow, moderate, and } \\
\text { fast). } \\
\text { It is not clear whether the GDV group included dogs that were } \\
\text { deceased as a consequence of the first GDV episode. It is possible } \\
\text { that referring veterinarians would not approach owners of dogs that } \\
\text { died or, alternatively, that owners whose dogs died were more or } \\
\text { less willing to be interviewed. This may have introduced bias into the } \\
\text { data set if survival rate from a GDV is associated with speed of } \\
\text { eating. }\end{array}$ \\
\hline
\end{tabular}

\begin{tabular}{|c|c|}
\hline \multicolumn{2}{|l|}{ Elwood (1998) } \\
\hline Population: & $\begin{array}{l}\text { Irish Setter dogs (both sexes, neutered and entire) owned by } \\
\text { members of UK Irish Setter Breed Clubs }\end{array}$ \\
\hline Sample size: & $\begin{array}{l}669 \text { dogs: } \\
\text { - } 75 \text { dogs that had had an episode of gastric dilatation and / } \\
\text { or volvulus } \\
\text { - } 594 \text { control dogs }\end{array}$ \\
\hline Intervention details: & $\begin{array}{l}\text { A questionnaire was sent to members of UK Irish Setter breed clubs, } \\
\text { and owners requested to complete one form per Irish Setter that } \\
\text { they had owned in the last ten years. } \\
\text { Demographic information included age, sex, neuter status and } \\
\text { whether the dog had ever had an episode of bloat/GDV. } \\
\text { Owners were requested to complete the answer by providing data } \\
\text { for the dog that applied at the time of the first GDV episode (GDV } \\
\text { dogs) or current data (control dogs). } \\
\text { A range of questions were asked about potential risk factors. These } \\
\text { included a range of dietary, environment, temperament and } \\
\text { exercise- related factors. }\end{array}$ \\
\hline
\end{tabular}




\begin{tabular}{|c|c|}
\hline Study design: & Cross-sectional study \\
\hline Outcome studied: & $\begin{array}{l}\text { Of specific relevance to this PICO, the owners were asked to rate } \\
\text { their dogs speed of eating from } 1 \text { to } 10 \text { ( } 1 \text { = very slow, } 10 \text { = very } \\
\text { fast). In the statistical analysis of this, the authors gender-and age- } \\
\text { matched control dogs to those of the GDV group. } \\
\text { There is insufficient information as to whether this was objectively } \\
\text { quantified (i.e. authors provided a descriptor for how fast each dog } \\
\text { should eat in order to be awarded a given score). Or, whether this } \\
\text { represented a subjective impression of the dog's feeding behavior. }\end{array}$ \\
\hline $\begin{array}{l}\text { Main findings: } \\
\text { (relevant to PICO question): }\end{array}$ & $\begin{array}{l}\text { Speed of eating was not identified as a risk factor for GDV. } \\
\text { The median }\left(1^{\text {st }} \text { quartile }-3^{\text {rd }} \text { quartile) score for speed of eating was }\right. \\
6(5-8) \text { for the GDV dogs, and } 7(2.1-8) \text { for the control dogs. }\end{array}$ \\
\hline Limitations: & $\begin{array}{l}\text { The questionnaire was asking owners to complete a form for every } \\
\text { Irish Setter dog that they had owned in the previous ten years. This } \\
\text { poses a number of related issues for the data: } \\
\text { - The dogs may not still be alive. Thus, it is not clear how the } \\
\text { owners of the dogs not affected (the control dogs) could } \\
\text { complete the questionnaire as per the instructions as the } \\
\text { dogs may have been dead at the time of completion. Do the } \\
\text { owners then complete the form based on the management, } \\
\text { exercise, feeding, etc routines of the dog shortly before it } \\
\text { died, or when it was younger/fitter/healthier? If the owners } \\
\text { all elect for the form (as the closest point to 'current') this } \\
\text { could introduce significant biases into the data set. } \\
\text { Up to ten years ago, is a long time to expect owners to } \\
\text { accurately reflect back and recall their dogs feeding, } \\
\text { exercise, housing regime, and so on. As the GDV group } \\
\text { owners were asked to recall this information from the time } \\
\text { the dog had its first episode of GDV, the length of time the } \\
\text { owners were required to reflect back could be even longer. } \\
\text { There is not enough information supplied regarding the speed of } \\
\text { eating score to allow further criticism of it. }\end{array}$ \\
\hline
\end{tabular}

\begin{tabular}{|l|l|}
\hline \multicolumn{2}{|l|}{ Raghavan (2004) } \\
\hline \multirow{2}{*}{ Population: } & $\begin{array}{l}\text { Dogs (male, female, neutered and entire) from eleven different large } \\
\text { and giant dog breeds (Akita, Bloodhound, Collie, Great Dane, Irish } \\
\text { Setter, Irish Wolfhound, Newfoundland, Rottweiler, Saint Bernard, } \\
\text { Standard Poodle, and Weimaraner), that were located within the } \\
\text { USA. Dogs were required not to have a medical history that included } \\
\text { an episode of GDV. }\end{array}$ \\
\hline Sample size: & $\begin{array}{c}318 \text { dogs were included: } \\
-\quad 106 \text { dogs that developed a GDV } \\
-\quad 212 \text { dogs that did not develop a GDV }\end{array}$ \\
\hline
\end{tabular}




\begin{tabular}{|c|c|}
\hline Intervention details: & $\begin{array}{l}\text { This study used dogs drawn from a larger study. The methodology } \\
\text { for this study is detailed above (Glickman, L. et al. 2000). } \\
\text { At the end of that prospective study, there was sufficient } \\
\text { information on diet and 'vital status' (not defined by authors, } \\
\text { presumed to be GDV development and other demographic } \\
\text { information matched for in the current study), for } 1634 \text { dogs to be } \\
\text { potentially included in this study. Of these, all dogs that developed a } \\
\text { GDV ( } n=106 \text { ) were included. } \\
\text { A nested case control study design was used so dogs that developed } \\
\text { a GDV were placed in one of six groups (corresponding to the year - } \\
\text { 1994 - } 2000 \text { - they experienced the episode of GDV). The dogs that } \\
\text { made up the control group ( } n=212 \text { ) were placed into one of six } \\
\text { groups according to the year they joined the study (i.e. the year they } \\
\text { completed the detailed questionnaire about diet, etc). From each of } \\
\text { these year groups, for every GDV case that occurred in that year } \\
\text { group, two dogs were randomly selected to act as controls. This was } \\
\text { done to ensure that the diet related information (including the } \\
\text { estimation of how fast the dogs ate) was collected at a similar time } \\
\text { for both GDV dogs and control dogs. }\end{array}$ \\
\hline Study design: & Case-control study \\
\hline Outcome studied: & $\begin{array}{l}\text { The outcome measure was whether the dog developed an episode } \\
\text { of GDV during the course of the study and whether it survived this } \\
\text { episode. The study then looked for breed related factors that were } \\
\text { associated with an increased risk of developing GDV in the } \\
\text { population studied. } \\
\text { Of relevance to this PICO, the authors asked owners to rate, on a } \\
\text { scale of } 1 \text { (slow) to } 10 \text { (fast), the speed with which their dog } \\
\text { consumed its food ration. The authors did not direct the owners } \\
\text { further as to what constituted e.g. a rating of ' } 3 \text { ', but, instead, the } \\
\text { owner was left to use their judgement and experience. } \\
\text { To analyse the data, dogs from each group were split into two } \\
\text { groups: slow eaters (score: } 1-3 \text { ); moderate speed eaters (4-6); fast } \\
\text { eaters ( } 7-10 \text { ) and odd ratios calculated based on difference from } \\
\text { moderate eating. Thus, both slow and fast rates of eating were } \\
\text { evaluated as a risk factor for GDV. }\end{array}$ \\
\hline $\begin{array}{l}\text { Main findings: } \\
\text { (relevant to PICO question): }\end{array}$ & $\begin{array}{l}\text { There was no significant effect of how quickly (or slowly) a dog ate, } \\
\text { on risk of developing a GDV. }\end{array}$ \\
\hline Limitations: & $\begin{array}{l}\text { The measurement of speed of eating on a scale of } 1-10 \text { will be } \\
\text { sensitive to owner subjectivity in assessment. }\end{array}$ \\
\hline
\end{tabular}


The authors collect data on eating speed at the start of the study (within 30 days of recruiting dogs). No further attempts were made to collect further data on this at regular intervals. Thus, unless speed of eating is an unchanged behavior of the individual dog and not influenced by other factors (e.g. diet change, age, etc), this reduces the ability of the study to detect real effects or meaningfully explain the effects observed.

\section{Appraisal, application and reflection}

This Knowledge Summary aimed to identify whether eating quickly increased the risk of GDV in dogs. It was concerned with being able to advise clients, who wish to use a device to slow down their dog's rate of eating in order to reduce the GDV risk, whether the use of these devices was warranted. The literature searches uncovered six papers (Glickman et al., 1997; Elwood, 1998; Theyse et al., 1998; Glickman et al. 2000; Raghavan et al., 2004; Pipan et al. 2012) that directly addressed the PICO question. Of these, four of the studies (Elwood, 1998; Theyse et al., 1998; Raghavan et al., 2004; Pipan et al., 2012) found no significant effect of speed of eating on risk of having a GDV episode. One paper (Glickman et al., 1997) found that dogs that ate quickly were significantly more likely to present at a clinic with a GDV episode. The final paper (Glickman et al., 2000) found that large breed dogs (but not giant breeds) were significantly more likely to develop a GDV if they ate fast, but the $95 \%$ confidence intervals associated with the relative risk value that the authors report suggests that the true risk may not differ from that of slow eaters.

The approaches used to assess speed of eating varied in both type and quality. The weakest of these studies in relation to the PICO question was the study by Theyse et al. (1998). The questionnaire asked owners to identify whether their dog consumed its meal in less than five minutes or more than five minutes. This apparently arbitrary cut off point may have been prone to ceiling effects (unpublished data by the author of this Knowledge Summary suggests most dogs will consume their ration within five minutes). Furthermore, it seems likely (based on the study methodology), that the authors were asking the owners to estimate 'time taken to consume meal' on the basis of recall of a dog that may have had a GDV episode as 10 years or more previously. Finally, the authors fail to provide any numerical data to support their finding so further examination of the results is impossible.

Where the studies provided information on the methodology used to assess speed of eating, most authors (Elwood, 1998; Glickman et al., 2000; Raghavan et al. 2004; Pipan et al. 2012) used a ratings scale approach to evaluate this. This approach was preferable to the Theyse et al. (1998) study as this removed the partial confound present between time taken to consume ration and size of the ration. Most of the scales were between 1-10 (Elwood, 1998; Glickman et al., 2000; Raghavan et al. 2004), but Pipan et al. (2012) used a scale of between 1- 5. None of the authors report providing descriptors to accompany each ratings score, but Glickman et al. (2000) reports leaving it to the owner's own judgment and experience (as Raghavan et al. 2004 also used a sub-section of this data this point will also apply to this study as they are not truly independent studies). This may have reduced the ability to find a true effect as owner judgement may be subjective and partially dependent upon other dogs owned and utilised as a comparator. It is not clear how, in the absence of a definition/descriptor to accompany each rating, the 1- 10 scale was any more useful than a 1- 5 scale.

The Pipan et al. (2012) authors fail to report the speed of eating findings within the results section. The authors then note in the discussion that there was no significant effect. However, this failure to report their finding adequately reduces the clinical and research value of this study. A failure to case match against potentially relevant dimensions (e.g. breed, size) may also have reduced the ability of this study to identify significant effects in at risk breeds as there may be many low risk breeds or size dogs that also eat fast. However, conversely this may also have reduced the risk that other causal factors that might correlate with 
speed of eating in high risk breeds and do cause increase risk of GDV, may wrongly lead to speed of eating being implicated a risk factor.

The Elwood (1998) study into risk factors for GDV specifically focused on Irish Setters and found no significant effect. However, the methodology employed in this study limited its ability to detect meaningful differences. Control dog owners were asked to provide current data for speed of eating; GDV dog owners were asked to provide speed of eating data that pertained to when the dog had its first episode of GDV. Thus, there is likely to be a difference in how long ago owners were being asked to reflect back and remember accurately their dog's speed of eating. This may be reflected in the data: median values did not differ between the two groups, but the variation around this median was much wider for control dogs, and much less (clustered relatively tightly round the median) for GDV dogs.

The Glickman et al. (2000) study focused on 11 large and giant breed dogs known to be high risk for GDV. This study reported that eating fast significantly increased risk in large, but not giant, breeds. However, the $95 \%$ confidence interval for the relative risk that they report for eating fast overlaps the odds ratio of 1.0 for slow eaters, indicating that the relative risk may not differ between the two groups. The giant breeds appeared to show the converse relationship when plotted graphically but this was not statistically significant. It cannot be discounted that it was underpowered to detect this effect statistically as the confidence interval associated with each speed of eating parameter (both large and giant dogs) was wide; however, given the number of giant breeds included $(n=738)$ this seems unlikely for any biologically important effect. Another issue surrounded dogs lost to follow-up as the authors failed to report this figure, but, from the information they do report, it seems likely that the loss to follow-up was high enough to severely risk invalidating the findings if participant losses were not random. The authors do not evaluate whether losses were random or systematically related to one of more of the participant characteristics or potential risk / protective factors for a GDV episode. The other main issue with this study was that it asked owners to rate their dog's speed of eating at the start of the study and then followed the dogs' outcome for up to 58 months. However, there is no evidence that speed of eating is a fixed behaviour trait that is unchanging over time. Interestingly, the Raghavan et al. (2004) study utilised a subset of data (all GDV cases, and twice as many controls, matched by year of GDV episode) that was collected and analysed for the Glickman et al. (2000) study and found no significant effect of speed of eating in either large or giant breed dogs. The authors report that the control and GDV dogs did not differ across dimensions such as age, breed or size. The use of a subset of the same data set and the failure to find a similar significant effect weakens the confidence that one might have in the findings of Glickman et al. (2000).

Finally, the Glickman et al. (1997) used dogs that presented at participating veterinary clinics with a GDV and case matched them with dogs of a similar age and breed (or size) that did not have an episode of GDV. This study found that, compared with slow eaters, eating as a moderate or fast speed, both significantly increased risk of GDV occurrence. However, the authors fail to mention in the methods section anything about collecting data on speed of eating, thus it is impossible to evaluate their methodology further in relation to this specific issue. This was a definite study weakness. Furthermore, the case matched dogs were (where needed), drawn from the authors' own university veterinary hospital. This was a source of bias in one other dimension (rural living), but is potentially a source of bias in other areas. It is not clear how rural living might affect speed of eating; however, it cannot be excluded as a potential risk for bias.

In conclusion, the evidence that eating fast is associated with an increased risk of GDV is mixed and inconclusive. The current studies that address this question are of variable quality and sometimes fail to report sufficient detail about either their methodology or results to facilitate adequate interpretation of the findings. However, it is worth noting that none of the studies found that eating slowly significantly increased the risk of GDV; where a significant effect was found, the increased risk of GDV was always associated with a faster rate of eating. Thus, if owners wish to slow down the rate at which their dog consumes it's meal, the veterinarian practitioner may advise that there is no evidence that this will increase the risk of GDV (though it may have no effect at all anyway). 


\section{Methodology Section}

\begin{tabular}{|c|c|}
\hline \multicolumn{2}{|l|}{ Search Strategy } \\
\hline $\begin{array}{r}\text { Databases searched and dates } \\
\text { covered: }\end{array}$ & Pubmed; Science Direct; Web of Science; CAB Abstracts (1973-2015) \\
\hline Search terms: & $\begin{array}{l}\text { (dogs OR dog OR canine OR bitch) AND ("gastric dilatation" OR } \\
\text { "gastric dilation "gastric dilatation volvulus" OR GDV OR "gastric } \\
\text { torsion" OR "stomach volvulus") AND (feed* OR diet* OR food*) }\end{array}$ \\
\hline Dates searches performed: & 28th September 2016 \\
\hline
\end{tabular}

\section{Exclusion / Inclusion Criteria}

Exclusion: Pre-defined exclusion criteria: non English language, popular press articles

Inclusion: Any comparative (control group utilised) study in which the effect of rate of feed intake on development of a gastric dilatation (+/volvulus) was investigated.

\begin{tabular}{|c|c|c|c|c|c|c|}
\hline \multicolumn{7}{|c|}{ Search Outcome } \\
\hline Database & $\begin{array}{l}\text { Number } \\
\text { of results }\end{array}$ & $\begin{array}{l}\text { Excluded - did } \\
\text { not answer to } \\
\text { PICO question }\end{array}$ & $\begin{array}{l}\text { Excluded - } \\
\text { not English } \\
\text { language }\end{array}$ & $\begin{array}{l}\text { Excluded - } \\
\text { conference } \\
\text { abstract only }\end{array}$ & $\begin{array}{l}\text { Excluded - } \\
\text { duplicates }\end{array}$ & $\begin{array}{c}\text { Total } \\
\text { relevant } \\
\text { papers }\end{array}$ \\
\hline NCBI PubMed & 32 & 26 & 0 & 0 & 0 & 6 \\
\hline $\begin{array}{l}\text { Thomson } \\
\text { Reuters Web } \\
\text { of Science }\end{array}$ & 33 & 26 & 1 & 0 & 6 & 0 \\
\hline CAB Direct & 58 & 49 & 1 & 2 & 6 & 0 \\
\hline Science Direct & 337 & 259 & 0 & 0 & 0 & 0 \\
\hline \multicolumn{6}{|c|}{ Total relevant papers when duplicates removed } & 6 \\
\hline
\end{tabular}

\section{CONFLICT OF INTEREST}

The author declares no conflict of interest. 


\section{REFERENCES}

1. Elwood, C. (1998) Risk Factors for Gastric Dilatation in Irish Setter Dogs. Journal of Small Animal Practice, 39 (4), pp. 185 - 190 http://dx.doi.org/10.1111/j.1748-5827.1998.tb03627.x

2. Glickman, L. et al (2000) Non-Dietary Risk Factors for Gastric Dilatation-Volvulus in Large and Giant Breed Dogs. Journal of the Veterinary Medicine Association, 217 (10), pp. 1492-

1499 http://dx.doi.org/10.2460/javma.2000.217.1492

3. Glickman, L. et al (1997) Multiple Risk Factors for the Gastric Dilatation-Volvulus Syndrome in Dogs: A Practitioner/Owner Case-Control Study. The Journal of the American Animal Hospital Association, 33 (3), pp. 197-206 http://dx.doi.org/10.5326/15473317-33-3-197

4. Pipan, M. et al (2012) An Internet-Based Survey of Risk Factors for Surgical Gastric Dilatation-Volvulus in Dogs. Journal of the American Veterinary Medicine Association, 240 (12), pp. 14561462 http://dx.doi.org/10.2460/javma.240.12.1456

5. Raghavan, N. et al (2004) Diet - related risk factors for Gastric Dilatation - Volvulus in dogs of high risk breeds. Journal of the American Animal Hospital Association, 40 (3), pp. 192-

203 http://dx.doi.org/10.5326/0400192

6. Theyse, L. et al (1998) Small Size of Food Particles and Age as Risk Factors for Gastric Dilatation Volvulus in Great Danes. Veterinary Record, 143 (2), pp. 48 - 50 http://dx.doi.org/10.1136/vr.143.2.48 


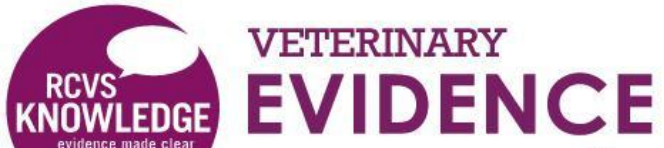 \\ online}

Intellectual Property Rights

Authors of Knowledge Summaries submitted to RCVS Knowledge for publication will retain copyright in their work, but will be required to grant to RCVS Knowledge an exclusive license of the rights of copyright in the materials including but not limited to the right to publish, re-publish, transmit, sell, distribute and otherwise use the materials in all languages and all media throughout the world, and to license or permit others to do so. Authors will be required to complete a license for publication form, and will in return retain certain rights as detailed on the form.

\section{Disclaimer}

Knowledge summaries are a peer-reviewed article type which aims to answer a clinical question based on the best available current evidence. It does not override the responsibility of the practitioner. Informed decisions should be made by considering such factors as individual clinical expertise and judgement along with patient's circumstances and owners' values. Knowledge Summaries are a resource to help inform and any opinions expressed within the Knowledge Summaries are the author's own and do not necessarily reflect the view of the RCVS Knowledge.

Veterinary Evidence and EBVM Network are RCVS Knowledge initiatives. For more information please contact us at editor@veterinaryevidence.org.

RCVS Knowledge is the independent charity associated with the Royal College of Veterinary Surgeons (RCVS). Our ambition is to become a global intermediary for evidence based veterinary knowledge by providing access to information that is of immediate value to practicing veterinary professionals and directly contributes to evidence based clinical decision-making.

www.veterinaryevidence.org

RCVS Knowledge is a registered Charity No. 230886. Registered as a Company limited by guarantee in England and Wales No. 598443.

Registered Office:

Belgravia House

62-64 Horseferry Road

London SW1P 2AF

This work is licensed under a Creative Commons Attribution 4.0 International License. 